\title{
Issues Identification and Its Solution through the Competitive Intelligence Application: The Case of Geothermal Power Plant Development in Rural Tompaso, North Sulawesi, Indonesia
}

\author{
Franky Reintje Tulungen ${ }^{1)}$, Wilmar Maarisit ${ }^{2)}$, Parabelem Tino Dolf Rompas ${ }^{3)}$
}

1) Agribusiness Study Program, Faculty of Agriculture, Universitas Kristen Indonesia Tomohon, Indonesia (E-mail: tulungen63@gmail.com)

2) Pharmacy Study Program, Faculty of Mathematics and Natural Sciences, Universitas Kristen Indonesia Tomohon, Indonesia (E-mail: wmaarisit@yahoo.com)

3. Informatics Engineering, Universitas Negeri Manado, Tondano, Indonesia (E-mail: parabelemrompas@unima.ac.id)

Corresponding author: tulungen63@gmail.com; +6281356613614

\begin{abstract}
The vision of the community around Geothermal Power Plant (GPP) is the development of GPP should be based on sustainable development principles, without jeopardizing the quality of life and justice for communities surrounding the power plant. This research aims to: (i) identifying issues that arise as an impact of the development of GPP in the rural Tompaso, and (ii) finding solutions to the issues to minimize the conflict that arises from further GPP development in rural Tompaso and its surroundings. This study is based on the competitive intelligence (CI) research method. The results show that the development of GPP in Tompaso has a negative impact on the natural environment and social environment. The technical solutions offered include: (i) bioremediation by cultivating plants that absorb arsenic; (ii) biosulfurization and desulfurization for reducing air pollution, especially sulfur; (iii ) floods and extreme drought are managed by improving infrastructure and reforestation; (iv) social conflicts (land acquisition, working days, labor recruitment and settlement security) are solved by intensifying program dissemination to the community and involving local communities in decision making. The recommended policy is providing incentives to the local community through strategic programs for the development of human and natural resources.
\end{abstract}

Keywords: GPP, environmental issues, CI, Rural Tompaso

\section{Introduction}

Indonesia's vision in 2045 is to become the 5th strongest country in the world with a GDP of US $\$ 7.3$ Trillion and a per capita income of US $\$ 25,000$. This can be realized by investment and trade;in industry, tourism, maritime, services, supported by reliable infrastructure and strong food, energy and water security. Indonesia has launched a new renewable energy mix in 2050 of $31 \%$ of the total national energy[1].One of the renewable and energy sources that have a strong commitment to the environment to support sustainable development is geothermal energy.

Law No. 30 of 2007 concerning Energy, it is stated that the National Energy Policy is prepared based on the principles of fairness, sustainability and environmental insight to support the creation of energy independence and national energy security. This policy confirms that energy diversification is a necessity to meet national energy needs.

In the industrial era 4.0, the development of electric energy generation is a necessity to meet the energy needs of Sulawesi Island, Eastern Indonesia. One of the available sources of electrical energy is a geothermal power plant (GPP). GPP is a power plant that uses geothermal energy as an energy source. 
The objective of the development of GPP is the availability of the geothermal energy to meet regional and national needs. It can be achieved by prioritizing the sustainable development principles without jeopardizing the quality of life and justice for the communities surrounding the plant.

Geothermal energy resources produce renewable energy that is clean and environmentally friendly. This energy is available in abundant quantities and can be exploited with many technologies [2][3]. The development of GPP is one of the important energy sources that produce green energy that is free of carbon dioxide emissions in the world [3][4], including in Indonesia.

The development of geothermal power plants is aimed at meeting national energy needs in the Industrial 4.0 era or in the era of community 5.0 (society 5.0) [4][5]. The availability of this energy in the framework of supporting national development so that the ideals of the Indonesian nation become the 5th strongest country in the world can be realized.

The development of geothermal power plants must be carried out by prioritizing the principles of sustainable development without endangering the quality of life and justice for the community around the geothermal power plant. This means that all progress caused by renewable energy is aimed at human welfare and improving the quality of the environment. [5][6]

However the GPP development initially will have a negative impact on the surrounding community (social environment) and the surrounding natural environment. These negative impacts include the emergence of social conflicts in the community and loss of water resources. Even the most extreme impact is that the surrounding communities have lost their homes, workplaces and business land due to the mudflows [7].

The construction of GPP is usually carried out by the urban community to the rural community. In this connection the urban community will bring technology and information to the rural community, otherwise the rural community will provide the material and energy available to the urban community. In this connection the urban community will exploit the village community [8]. In this connection, efforts and policies are needed to balance the relationship between the two ecosystems so that the negative impacts can be resolved.

Research on the problems posed by the development of geothermal power plants in rural areas and research related to their solutions is still relatively few carried out by researchers. Natural environmental problems related to water pollution by arsenic can be solved by planting special plants that can absorb arsenic in the wastewater reservoir [9] [10] and air pollution by $\mathrm{H} 2 \mathrm{~S}$ can be solved by desulfurization and bio-desulfurization [11]. While research on the impact of the social environment is still very little done by researchers [12]. However, comprehensive research related to natural and social environmental impacts and its solutions is needed to be carried out to provide comprehensive information for stakeholders, including local communities.

The North Sulawesi Lahendong GPP has been operating since 2001 and is currently producing electricity with a total capacity of $120 \mathrm{MW}$. This has meets the 60 percent of electrical needs in the North Sulawesi province. The Lahendong GPP already has 6 (six) GPP units each producing $20 \mathrm{MW}$, of which the lasts 2 (two) units, namely units 5 and 6 are in Tompaso[9].The GPP in Tompaso has acquired around 19 ha of land, 9 ha of which are paddy fields. GPPTompaso has 6 production wells and 2 injection wells.

The implementation of the well drilling project and the construction of the GPP in Tompaso had been caused problems for some people around the well fields and the geothermal power plant construction site. Because of that many residents refuse the presence of the project GPP for unit 8 that will be set up near water sources. 
Based on that facts, the question that arises are: (i) what are the negative impacts caused by the development of the GPP project on the social environment and natural environment in rural Tompaso, and (ii) what are the solutions to solve the negative impacts caused by the GPP project development in rural Tompaso?

Based on these problems, the aims of this study are to identify problems in the community caused by the development of GPP in rural Tompaso and to find solutions to these problems to minimize conflicts arising from future GPP development in rural Tompaso and its surroundings.

The benefits of this research is to provide input for PertaminaGeothermal Energy (PGE), the government and surrounding communities in geothermal management, which on one hand can meet national energy needs and on the other hand maintain the preservation of the natural environment as well as improve the quality of the social environment.

\section{Research Methods}

This research was conducted from January to June 2019 in Tompaso District, Minahasa Regency, North Sulawesi Province, Indonesia, especially in units 5 and 6 of GPP.This study is based on research uses competitive intelligence research method (CI) as a policy research method[10][11]. Competitive intelligence is a systematic program in collecting, analyzing data and information as well as understanding information in the context of compiling recommendations to answer problems faced by the organization[12][13]. CI is a method of approach and set of tools to help create intelligence[10]. CI is a circular process[14][15](Figure 1).

\section{Cl Process (Intelligence Cycle)}

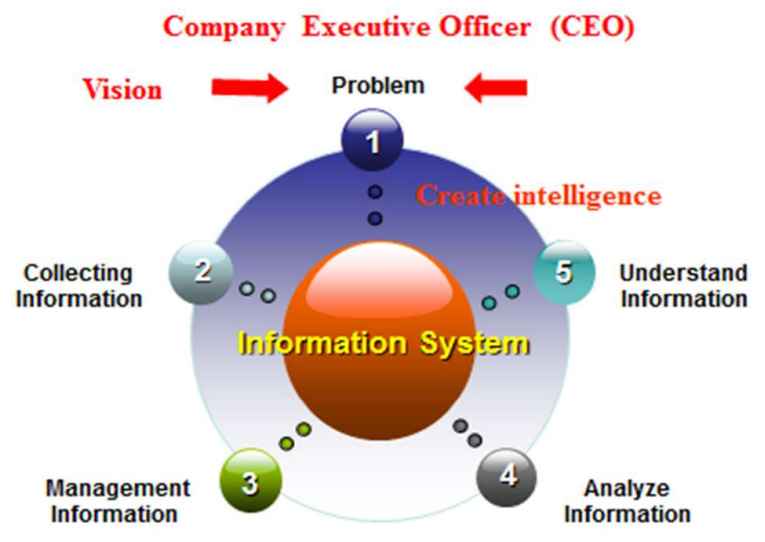

Figure 1.Competitive Intelligence process[16].

Starting from the existence of a vision[16], but in realliaty problems arise relating to the achievement of the intended vision[6]. Based on the research problems, an information-gathering plan was developed to solve the problems. The information collected is primary information and secondary information[12][6]. Primary information is aimed more at answering the first goal and secondary information is aimed more at answering the second goal. Sources of primary information are informants involved in the PGE project and the people who influenced directly by 
the development impact. Information are collected through open-ended interviews with the informants and through direct observation at the project and affected locations. Secondary information are from documents, such as textbooks, reports, scientific journals, and other documents. The collection of secondary information is mostly done through the internet sources.

Data analysis is done by grouping the data according to themes, namely the social environment or the natural environment. Each can be distinguished into sub-themes until it creates a unified whole and meaning. The results of the data analysis are then understood (through a deep and more comprehensive thought process) so that intelligence can be created as a recommendation for solving negative issues and further consideration for PGE and the surrounding community[6].

\section{Results and Discussion}

\subsection{The natural environment}

\subsubsection{Water pollution}

Water pollution occurs in two ways, first at the time of well drilling and second at the end of the drilling. During the drilling, the problem of the drill bit being released at the time of drilling due to the drill bit hit a solid material. To remove the drill bit, the well that has been dug is filled with thousands of liters of diesel oil. As a result groundwater is polluted with the diesel oil. After the drilling is completed, water or water evaporation coming out of the well is discharged into the reservoir. This water may contain toxic heavy metals such as arsenic. Because the reservoir cannot accommodate this wastewater at certain times, it overflows into the surrounding ground. As a result, surface water or ground water becomes polluted by arsenic.

Surface or ground water that is polluted with arsenic will contaminate plants to be planted such as rice with arsenic. The ground water that is used for drinking water by humans and animals will be contaminated with arsenic ${ }^{7}$.

Based on the research by Hariyadi, the quality of waste water from the Lahendong Geothermal Power Plant is poor consist of high arsenic concentrations of $1.2 \mathrm{mg} / \mathrm{L}$ (at point 1) and $1.26 \mathrm{mg} / \mathrm{L}$ (at point 2)[17]. This amount exceeds the limit value that can be tolerated, which is $0.05 \mathrm{mg} / \mathrm{L}$ for arsenic[18]. Exposure to arsenic can trigger liver, kidney and skin cancer and also heart disease. Consuming arsenic-contaminated water can cause miscarriages, low birth weight babies and poor cognitive development in children[19].

Water pollution by arsenic can be overcome by improving waste water storage tanks and treating the wastewater[20]. Planting the surrounding area with the Monochoria vaginalis, Salvinia molesta and Colocasia esculenta will help reduce the arsenic concentration due to their ability to absorb arsenic in wastewater from Geothermal Power Plants. The highest arsenic absorption occurred at the root of Monochoria vaginalis $(22,289 \mathrm{mg} / \mathrm{kg}$ ) then followed by the root of Salvinia molesta $(19,2335 \mathrm{mg} / \mathrm{kg})[21]$.

\subsubsection{Air pollution}

Air pollution is caused by increasing sulfur content (H2S) in the air. Air pollution occurs both around the well or GPP as well as in locations far from wells in Tompaso district. The level of pollution in the area around the wells is higher than the area far from the wells. This air pollution can be easily detected, such as corrosion on the zinc roof faster than usual. This air pollution can also be seen from affected plants around the well, such as tomato plants that fail to bear fruit. In addition, rice production per ha islower compared to before the drilling of wells by PGE. For example, if farmers were able to harvest 15-20 bushels per waleleng, now they can only harvest 10 bushels per waleleng. 
The increase in sulfur content in the air will cause the opening of greenhouse gases below the earth's surface. With the existence of GPP, the emission of these gases will reach the surface of the earth and therefor can pollute the air in its surrounding. Experience from what happened in New Zealand, shows that the air around the Wairakei Power Station was also polluted by carbon gas, including sulfuric acid gas $(\mathrm{H} 2 \mathrm{~S})^{11}$.

To reduce the sulfur levels from the well into the air can be done by desulfurization. The higher the concentration of $\mathrm{Na} 2 \mathrm{CO} 3$ solution, the more $\mathrm{NaHS}$ is absorbed where at a concentration of $11 \%$ can reduce $\mathrm{H} 2 \mathrm{~S}$ gas by $87.86 \%$. In other words if the concentration of H2S gas emissions from GPP activities ranges from 4800-6600 ppm, then with the absorption process the H2S gas emitted into ambient air decreases to 582-801 ppm. With the process of bio-desulphurization (Rhodococcussp) the formed sulfur crystals were an average of $52.01 \%$ on a field scale and an average of $71.28 \%$ on a laboratory scale[22]. Decreasing the quantity of production due to sulfur exposure needs to be sought technological innovation to obtain plants that are resistant to high-producing sulfur.

\subsubsection{Flood and Drought}

Changes in land use from paddy fields to other crops and other uses have caused the water reservoir area to become narrow. As a result, if there is high intensity of rain it will cause flooding in the fields around the drilling that can impact the rice production.

Changes in land use from forest land to barren land have caused a reduction in water resources around the site. Tree clearing due to land clearing for the GPP project and drilling have caused the loss of several of the springs around the GPP Project. Water sources that irrigate rice fields in several villages in the Tompaso sub-district are demising. Areas in the downstream part of the GPP project are very vulnerable to drought and the loss of water has resulted in yearly loss harvest.

Floods and droughts can be overcome by improving infrastructure, such as the normalization of the Panasen River, and improving vegetation on the headwaters by building community forests or reforestation. This includes the requirement for PT Geothermal Energy Lahendong to expand the area cleared for drilling wells from 5 (five) hectares to 10 (ten) hectares, of which 5 (five) additional hectares are designated as village forests.

\subsubsection{Conversion of paddy fields to drilling fields}

The geothermal development project in Tompaso has closed around 9 ha of rice fields. Of this amount 5 hectares for drilling wells and 4 hectares for water pipeline from production wells to injection wells. This is contrary to the government policy regarding the acquisition of paddy fields. Rice fields that are converted into drilling sites should be substituted with the same amount of land, but in reality there is no substitution of rice fields. In the future it is necessary to consider rice fields as a final consideration in determining the location of well drilling. Besides that, every productive land acquisition must be replaced by another land[23]. The decision to locate the project on the paddy fields should be the last alternative, besides that, an effort should be made to locate the project far from the settlement.

\subsection{Social Environment}

\subsubsection{Land acquisition conflict.}

Public concern first arises when the land acquisition occurs. The concern is due to the lack of the PGE effort to let people know the location of the project and the land acquisition. The time when the land acquisition happened before people know where location and acquisition will occur. In addition, conflicts happened between members of the families who need to sell the land to the project. This is due to the fact that there are family members who have received the compensation of the family owned land without the knowledge of other family members. 
To prevent the conflict during land acquisition, early socialization is needed in order for the local people to correctly understand the project planning and implementation. Furthermore, the surrounding community should be involved in the decisions making related to land acquisition and the fixed prices of the land.

\subsubsection{Worker recruitment conflict.}

Worker recruitment is carried out by a contracting company assisted by a Working Group. The Working Group consists of Village Heads (HukumTua) surrounding the well or the GPP.Worker recruitment for skilled labor was carried out directly by the contractor and for unskilled labor, such as security workers and day laborers, were carried out by the Village Heads (HukumTua) as a member of the working group in their respective villages. Even though the village heads were involved, the recruitment conflict of workers always occurred. There are two kinds of conflicts occurred, namely between the Village Heads and the people who want to work and secondly between the contractor and PGE Lahendong and the people around the project. The Village Heads used their authority in recommending the workers who are only close to them. The contractor recruits people whom they think can help protect their interests during the project. As the result, people who were not recruited revolted against the Village Heads and community leaders revolts against the contractor and PGE Lahendong. This is due to this fact that there were jealousies from the people, that only certain people were accepted, namely people who were close to the working group and people who had relation to the contractor and PGE Lahendong work for the project. This conflict had encouraged people who were not included to demonstrate and rebel against the decision. During the GPP development projects there have been more than 10 demonstrations carried out by the local community with various demands, such as asking for the PGE Lahendong to socialize the project, requesting transparency by about employment opportunities, and refusing workers from outside Tompaso to works in the projects. In addition to that, the local workforce can only meet the needs of low and specialized skilled workers, who do not require skills.

Related to the conflict of the employee recruitment, the project needs to inform the community about the needs of the workforce, including the specifications of the needed workforce, including the specification of the workforce, involvement of community and religious leaders in the determination of workers, and should pay attention to community representation in the project.

\subsubsection{Working Days and Hours of Operation}

In the process of GPP project development in Tompaso, the working days are Monday through Saturday. Developers donot recognize holidays, especially Sundays. The culture of the local community is to forbid people to work on Sundays, especially during worship hours. This working day on Sunday has initiated protests from local community. In addition, the noise and vibration caused from drilling wells are very disturbing during worship activities in the Church.

Conflict about days and hours of operation can be solved by communication between community leaders / religious leaders and the developer. For example, there should be recess on Sundays especially during church services.

\subsubsection{Settlement Security}

The existence of the GPP project has brought two kinds of fears among the village community. Firstly, local people worried about security and order with an addition the entry of numerous of workers from outside the community from different cultural backgrounds. Secondly, the existence of the GPP project that could be brings misfortunes to the community, namely the mud disaster or the decline in the surface of the land. This is influenced by the recent disaster from the Lapindo Mud story in East Java that has drowned several villages surrounding theLapindo 
Geothermal Plant[7] and the results of research in units 1 and 2 in the Lahendong GPP exploitation area which had reduced the land surface level by 3 to $4 \mathrm{~cm} 1[24]$.

The concern due to the incoming workers from outside of the area who live together within the village community can be reduced when there is a good interaction within the local community. Public concern about the fears of Lapindo's effect to the community can be overcome by public awareness that the Lapindo mudflow incident was not caused by drilling but rather due to the natural disasters that happened in East Java.

GPP development is intended to meet the need of the national energy by promoting the principle of sustainable and equitable development. To meet this goal, we need to pay attention to the issue that have been emerging in the village and also learn from the many experiences that have happened and happening from other region and countries.

Tompaso's GPP as an energy generator must be supported by all stakeholders. GPP existence must be able to improve the quality of the natural environment (water, air, soil, sunlight, plants and animals) and the quality of the social environment (education, health, economy, culture, law, and so on), especially the local environment where the project or business in.

Local people are those who produce geothermal energy or energy producers and outsider are energy users. In relations between communities (environmental systems), in a natural state, a more stable system (cities, elite groups) will exploit less stable systems (villages, marginal groups, etc.). Energy and matter will flow from the village to the city[8]. Based on this fact, it is necessary to intervene by certain parties, to create a balance, between villages and cities, between the social environment and the natural environment, and between marginalized groups and elites by means of providing incentives for villagers so that the principles of sustainable development and justice can be realized.

The role the Government, Pertamina, PLN and surrounding communities are very important in maintaining the balance between the social environment (social system) and the natural environment (ecosystem), and the balance between villages and cities. Energy will flow from the village to the city, so to balance the two ecosystems, the material and information from the city must be conveyed to the village. For this reason, strategic programs are needed to improve the quality of the social and natural environment

\section{Conclusions and Recommendations}

\subsection{Conclusion}

Problems the existence of GPP development includes: (i) Natural Environment: water pollution by arsenic, air pollution by sulfur, floods and drought, conversion of paddy fields to dry fields, (ii) Social environment: conflicts of land acquisition, recruitment workers, working days and hours of operation and security of local resident. Some solutions to the natural environmental problems are (i) water pollution, such as exposure to arsenic in water can be overcome by increasing wastewater collection basins and wastewater treatment, (ii) air pollution and reduced crop production by sulfur can be overcome by desulfurization, and (iii) floods and drought can be overcome by improving infrastructure and reforestation. Solutions to social environmental problems such as (i) land acquisition, (ii) working days and hours, (iii) recruitment of workers, and (iv) security of settlements around the GPP Project can be overcome by program socialization to the community and involving local communities in decision making. 


\subsection{Recommendation}

Recommendations that can be proposed are: (i) In the context of determining the location and recruitment of local community workers, the decision making must be involved the local community, (ii) Local residents must gain benefits or incentives from the energy that is produced through a strategic program and cooperation with the community in the context of developing human and natural resources, and (iii) Cooperation between the Government, PGE, and Universities is needed in order to find innovations to address problems in the field, such as finding plants and vegetation that are resistant to sulfur.

\section{Acknowledgment}

This research was funded by the Tomohon Indonesian Christian University (UKIT) through a research grant program from the Research and Community Service Institute (LPPM) in the 2019 academic year.

\section{References}

[1] Kememterian PPN/Bappenas, Indonesia 2045 Berdaulat, Maju, Adil dan Makmur. Jakarta: Kementerian Bappenas, 2018.

[2] L. Zhang, S. Chen, and C. Zhang, "Geothermal power generation in China: Status and prospects," Energy Sci. Eng., vol. 7, no. 5, pp. 1428-1450, 2019, doi: 10.1002/ese3.365.

[3] M. F. Hossain, "In situ geothermal energy technology: An approach for building cleaner and greener environment," J. Ecol. Eng., vol. 17, no. 1, pp. 49-55, 2016, doi: 10.12911/22998993/61189.

[4] Anonimous, "Mengenal Visi Jepang Society 5," 2019. .

[5] M. Fukuyama, "Society 5.0: Aiming for a New Human-centered Society," Japan SPOTLIGHT, vol. 27, no. Society 5.0, pp. 47-50, 2018.

[6] F. R. Tulungen, Pertanian Cerdas Cengkeh Sulawesi Utara di Era Industri 4.0 dan Masyarakat 5.0. Malang: DeePublish, 2020.

[7] A. Farida, "Jalan Panjang Penyelesaian Konflik Kasus Lumpur Lapindo," J. Ilmu Sos. dan Ilmu Polit., vol. 17, no. 2, pp. 144-162, 2013, [Online]. Available: https://doi.org/10.22146/jsp.10880.

[8] A. T. Rambo, "Conceptual Approaches to Human Ecology East-West Center," no. 14, pp. 1-24, 1983, [Online]. Available: https://scholarspace.manoa.hawaii.edu/bitstream/10125/21316/1/Conceptual Approaches to Human Ecology.pdf.

[9] “PLTP Lahendong Unit 5 dan 6 Sepanjang 2019," Dunia Energi. .

[10] H. Dou, A. Juillet, and P. Clerc, Strategic Intelligence for the Future 1. New York: ISTE Ltd, London and John Wiley \& Sons, 2019.

[11] F. R. Tulungen, J. Lengkong, R. P. Karuntu, M. J. Oping, and F. S. Rumondor, "Program Strategi untuk Meningkatan Keuntungan Usahatani Cengkeh Berdasarkan Analisis Struktur Biaya di Minahasa, Sulawesi Utara," J. Front., vol. 3, no. 1, pp. 19-25, 2020.

[12] H. J.-M. Dou and S. D. Manullang, Competitive Intelligence, Technology Wath and Regional Development. Jakarta: MUC Publishing, 2003.

[13] F. R. Tulungen, “Cengkeh Dan Manfaatnya Bagi Kesehatan Manusia Melalui Pendekatan Competitive Intelligence," J. Boifarmasetikal Trop., vol. 2, no. 2, pp. 158-169, 2019, [Online]. Available: https://journal.fmipaukit.ac.id/index.php/jbt/article/view/128/93. 
[14] L. Kahanner, Competitive Intelligence, How to Gather, Analize, and Use Information to move your business to the Top, 1st ed. New York: Touchstone, 1997.

[15] D. Vriens, "The Role of Information and Communication Technology in Competitive Intelligence," in Information and Comunication Technology for Competitive Intelligence, D. Vriens, Ed. London: IRM Press, 2004, pp. $1-33$.

[16] F. R. Tulungen, Competitive Intelligence for the Regional Development in Indonesia, Strategi for the Development of Clove Small Entreprises in Minahasa, North Suawesi. Saarbrucken, Germany: LAP Lambert Academic Publishing, 2012.

[17] Hariyadi, Soemarno, B. Polii, and B. Yanuwiadi, "Feasibility Analysis of Geothermal Power Plant Wastewater Utilization: A Case Study on Lahendong Geothermal Power Plant, North Sulawesi," Int. J. Basic Appl. Sci. IJBAS-IJENS, vol. 12, no. 06, pp. 187-190, 2012.

[18] "Peraturan Pemerintah Republik Indonesia Nomor 82 Tahun 2001 tentang Pengelolaan Kualitas Air dan Pengendalian Pencemaran Air," 2001. .

[19] Direktorat Pengawasan Produk dan Bahan and B. P. Deputi Bidang Pengawasan Keamanan Pangan dan Bahan Berbahaya, "Arsen Trioksida." .

[20] D. A. Mohammed Barznji, "Potential of some aquatic plants for removal of arsenic from wastewater by green technology," Limnol. Rev., vol. 15, no. 1, pp. 15-20, 2015, doi: 10.2478/limre-2015-0002.

[21] B. Yanuwiadi and B. Polii, "Phytoremediation of arsenic from geothermal power plant waste water using Monochoria vaginalis, Salvinia molesta and Colocasia esculenta," Int. J. Biosci., vol. 3, no. 6, pp. 104-111, 2013, doi: 10.12692/ijb/3.6.104-111.

[22] M. Munir, K. Haryanto, I. Novarina, B. Mariena, and S. Indrati, "Pemulihan Sulfur pada proyek PLTP dengan desufurisasi.pdf," J. Ris. Ind., vol. 4, no. 3, pp. 1-10, 2010, [Online]. Available: http://ejournal.kemenperin.go.id/jri/article/view/85/86.

[23] "Peraturan Pemerintah Republik Indonesia Nomor 1 Tahun 2011 tentang Penetapan dan Alih fungsi lahan Pertanian Pangan Berkelanjutan," 2011. .

[24] R. Kurniawan and I. M. Anjasmara, "Pemanfaatan Metode Differential Intermerometry Synthetic Aperture Radar," J. Tek. ITS, vol. 5, no. 2, 2016, doi: DOI: 10.12962/j23373539.v5i2.17361. 